\title{
Jeff Kingston: A modern Japán kihívásai
}

\author{
Herczeg Fanni: Jeff Kingston: Contemporary Japan: History, Politics, and Social \\ Change since the 1980s
}

Manapság itthon kevés olyan átfogó irodalommal találkozhatunk, amely komplex betekintést enged a Japánban jelenleg zajló folyamatokba, illetve a szigetországot érintő aktuális kihívásokba. E hiány pótlására adták ki magyar nyelven Jeff Kingston amerikai származású Ázsia-kutató egyetemi tanár könyvét, A modern Japán kihívásai címen. A kötet az 1980-as évek végétől egészen a 2010-es évek elejéig elemzi a szigetország életét leginkább formáló eseményeket, többek között említést tesz a demográfiai változásokról és azok következményeiről, valamint a japán császári hagyományokról. Ugyan a kötet eredeti (angol) nyelven 2010-ben jelent meg az Amerikai Egyesült Államokban Contemporary Japan: History, Politics, and Social Change since the 1980s címen, első kiadását nem jelentették meg magyar nyelven. Fordítását a második kiadás alapján - amit 2013-ban adtak ki - Sándor István végezte el, a kötet szerkesztéséért Orosz Ildikó, szakmai lektorálásáért pedig Schwacz Emese felelt. A kötet hazai megjelenésére a magyar olvasóközönségnek 2018-ig várnia kellett, ez magyarázza, hogy a 2013 után bekövetkező eseményekre és az ezekből következő kihívásokra a könyv nem tér ki.

A mű külső fizikai megjelenése első ránézésre markánsan eltér az eredeti nyelvű kiadásokétól. Elsősorban a borító tekintetében találkozhatunk lényeges különbségekkel, hiszen míg az angol kiadásoknál a modern megjelenítésre és az egyszerüségre törekedtek, addig a magyar kötetnél az Antall József Tudásközpont elegáns megoldásokkal, mégis letisztultan igyekszik felhívni a hétköznapi ember figyelmét a müre. A borító keménykötésü, barátságos színvilágú, esztétikus, mégis közelebbről megvizsgálva egyértelmüen beazonosítható a könyv témája akár a képi eszközöket tekintve is. A magyar és az angol kiadások címükben eltérnek, hiszen míg az eredeti nyelvü kiadások esetében (Contemporary Japan: History, Politics, and Social Change since the 1980s) törekedtek a téma minél pontosabb lehatárolására a címben, addig ezt a magyar kiadásban (A modern Japán kihívásai) elhagyták. Ugyan a legtöbb esetben szükséges egy bizonyos fokú változtatás eszközölése a címadás terén fordítói munka végzésekor, ugyanakkor megemlítendő, hogy e változtatással a magyar és az angol nyelvű olvasó első benyomása a müről eltérhet. A mű törzsszövege meghaladja a 340 oldalt, amelyet - a témában kezdők számára is nagy segítséget nyújtó - egy, az idegen szavak megértését célzó szójegyzék is kiegészít. A szójegyzék mellett a kötet végén található további irodalom az egyes fejezetekre és alfejezetekre vonatkozóan, valamint egy név- és tárgymutató, amelynek alapvető funkciója az olvasmány gyorsabb megértését szolgálja. Ábra- és képi anyagokban nem kiemelkedő, hiszen mindössze egyetlen térképi ábrázolással találkozhatunk a 7. oldalon. Ez ugyan ellátja funkcióját, mégis bizonyos fejezeteknél - többek között harmadik fejezet: Közpolitikák és következményeik - az egyértelmüsítés érdekében bizonyos adatok (választási eredmények) esetében az ábrákkal való szemléltetés 
célszerübb megoldás lehet. A kiadvány tehát esztétikai szempontból kiemelkedő, hiszen alapvetően sikeresen ragadja meg és tartja fenn az olvasó figyelmét.

Az egyes témaköröket Kingston igyekszik semleges módon, saját tapasztalataitól mentesen bemutatni, a legnagyobb részben sikeresen. Ugyanakkor már a fejezetválasztások tekintetében is fellelhető bizonyos fokú elfogultság. Többek között megemlítendő, hogy ugyan lényegesek a Japán területén bekövetkezö, a szigetország biztonságát érintő belső folyamatok - amelyeket a szerző leginkább kiemel - mégsem tekinthetünk el azon tényezőktől és kihívásoktól, amelyek a kelet-ázsiai ország határain kívülről érkeznek (Kína újbóli felemelkedése, Észak-Korea folyamatos fegyverkezése). Hiszen a mai globalizált világban gyakran értelmezhetetlenné válnak az egyes biztonsági folyamatok, ha nem kontextusba illesztve, esetleg egy országcsoport vagy régiók szintjén vizsgáljuk őket.

A magyar kiadásban a japán szavak átírásakor a szerző által alkalmazott egyszerüsített Hepburn-féle átírást alkalmazták különösebb változtatások eszközölése nélkül (ez alól kivételt képeznek a közkeletü földrajzi nevek, amelyek átírása a Magyarországon elterjedt formát követi). Ebből következően sem az angol, sem a magyar nyelvü kiadásokban nem jelölik a hosszú magánhangzókat előfordulásukkor, ami a szerzővel szemben kritikaként is megfogalmazható. A magyar fordítói és szerkesztői csoport részéről ugyanakkor kiemelendő az a döntés, hogy az itthon megszokottal ellentétben meghagyták a Hepburn-féle átiratot, amit a témában otthonosan mozgók is egyre inkább preferálnak.

Ahogy azt a fentiekben már említettem, az eredeti cím határolja le leginkább a kötet mondanivalóját, amelyben a szerző kiemeli a szigetország történelmét, politikáját, valamint szociális változásait. Mindemellett Kingston külön fejezetet szentel a környezettel és bizonyos intézményekkel (császári család, Jakuza) kapcsolatos kihívásoknak is. Ezzel összhangban megjegyzendö, hogy a kötet rengeteg témát felölel; igyekszik egy átfogó és komplex látásmódot átadni, amit bizonyos témaköröknél (például észak-koreai kisebbség) felületesen tud csak megtenni. Ebből az okból kifolyólag a szerző a fejezetekhez a kötet végén csatolt külön további ajánlott irodalmakat mindazok számára, akik az általuk preferált témákban szeretnének elmélyülni.

A kötet belső felépítését tekintve hat nagyobb részből áll, a témaköröknek megfelelöen ezekhez különbözö fejezetek és alfejezetek kapcsolódnak. Minden nagyobb témakört követően a szerző összegzi saját gondolatait a jövőre vonatkozóan, amelyek többek között össze is foglalják az addig leírtakat. Az első részben ugyan egy rövid történelmi összefoglalóval találkozhatunk, ám mivel a kötet napjaink Japánjának kihívásaival foglalkozik, ezért ez a rész leginkább azt a célt szolgálja, hogy átadja az ezt követő részek és fejezetek megértéséhez szükséges ismereteket, és ne egy történeti szintézisként vegye ki részét a kötetből. A Kockázatok és következmények részben olyan kihívásokat említ, amelyek nemcsak a szigetországot, hanem legtöbbször a fejlett országok többségét is érintik; itt Japán szociális és demográfiai trendjeivel foglalkozik, külön kiemelve a népességcsökkenést és következményeit, a családok, a gyermekek és a nők helyzetét, valamint a munkahelyekkel kapcsolatos kihívásokat. A Közpolitikák és következményeik részben foglalkozik a 2013 elötti fontosabb politikai változásokkal és eseményekkel, valamint kiemeli a szigetországra jellemzö közpolitikák fenntartásának kérdéskörét. Ebben a részben kitér még a - folyamatos nézeteltérések tárgyát képező - japán alkotmány 9. cikkének megváltoztatásával kapcsola- 
tos kihívásokra, a Japánban élő kisebbségek helyzetére, valamint a második világháborús japán rémtettek (többek között nankingi mészárlás) felvállalásával kapcsolatos vitákra és az erre ható japán nacionalizmusra. Két érdekesség is felmerül a japán alkotmány 9. cikkével kapcsolatos viták vonatkozásában: az egyik, hogy az alkotmány szövegének a megváltoztatására a mai napig nem került sor, annak ellenére sem, hogy a jelenlegi miniszterelnök, Abe Shinzō mindent megtett ennek érdekében; a másik a Japán Önvédelmi Haderővel (Japanese Self-Defence Forces) kapcsolatos, ugyanis sokan megkérdőjelezik azt is, hogy az alkotmány enged-e egyáltalán teret egy ilyen szerveződés létének. Annak ellenére, hogy a harmadik részben rengeteg számadat szerepel, a szerző az események leírásakor stílusával sikeresen tartja fenn az olvasó figyelmét, nem túlterhelő számmennyiséget tár elénk, éppen annyit, amennyi szükséges bizonyos szituációk átlátásához.

Az utolsó két fejezetben olyan kihívásokat említ, amelyek a hétköznapi ember figyelmét sem kerülik el, amikor Japánról van szó. A negyedik részben a szerző a környezeti problémákra helyezi a hangsúlyt, aminek során külön fejezetet szentel a 2011. március 11-ei katasztrófának. Indokoltan, hiszen ez volt a szigetországban bekövetkezett egyik legnagyobb emberáldozatot követelö földrengés, cunami és nukleáris katasztrófa. Részletezi az előzményeket, a katasztrófát okozó személyek és intézmények tevékenységét, kiemeli a jakuza tevékenységét a szerencsétlenség utáni helyreállítási munkálatokban, valamint említést tesz a katasztrófa hosszú távú hatásairól mind környezeti, mind pedig humánegészségügyi szempontból. Az ötödik részben, amelynek az Intézmények veszélyben címet adta, Kingston olyan érdekességekkel és kuriózumokkal foglalkozik, mint a császári család és a Jakuza. A császári családdal kapcsolatban több témát érint a szerző, többek között kiemeli a japán császár második világháborús felelősségre vonás alóli felmentését, valamint beszél az utódlással kapcsolatos nehézségekről, amelyek az idő elteltével folyamatosan egyre égetőbbé válnak. A változások tekintetében érdemes utánanézni a tavalyi év eseményeinek, hiszen egyedülálló módon 200 év elteltével most elöször mondott le japán császár a trónról fia javára. A Jakuza rengeteg regény, kalandfilm és akciófilm alapját képezi, mégis manapság egyre kisebb népszerüségnek örvend az egykor virágzó szervezett bünözői csoportosulás. Kingston a kötet utolsó nagy fejezetében ennek az okait kutatja. Kiemeli: annak ellenére, hogy egyre kevesebb taggal büszkélkednek, a japán szervezett bünözői csoportok világviszonylatban még ma is meghatározók, hiszen taglétszámuk magasan meghaladja a világ más részein tevékenykedő szervezett bünözői csoportosulások létszámát. A kötetben olvashatunk a Jakuza virágzásáról az 1980-as években, a különböző katasztrófák során mutatott tevékenységéröl, valamint arról, hogy manapság milyen módon csökken nehezen felépített presztízsük a japán társadalmon belül.

A modern Japán kihívásai összességében egy hiánypótló és izgalmas kiadvány, természetesen, ahogy minden kötet, ez is rendelkezik kisebb hibákkal, mindemellett ezek eltörpülnek azon pozitívumok mellett, amelyeket a mü és szerzője nyújtani tud. Egy olyan monográfiáról beszélünk, amelynek fordításába is rengeteg munkát fektettek. Ezt mutatja az is, hogy a magyar kiadás megőrizte a szerző stílusának könnyedségét és rugalmasságát, miközben informatív jellegét sem vesztette el. Könnyü szívvel ajánlott mindenki számára. 